\title{
Business Model Adaptation of Small and Medium-Sized Information Technology Firms:
} The Role of Dynamic Capabilities

\author{
Yulong Liu, Massey University, New Zealand \\ (iD) https://orcid.org/0000-0002-5762-7854 \\ Yang Yu, Victoria University of Wellington, New Zealand \\ (iD) https://orcid.org/0000-0002-7464-2079
}

\begin{abstract}
Small and medium-sized information technology firms operating in high-velocity business environments have to continuously adapt their business models. Prior research on business model adaptation, however, remains under-developed. In this study, the authors address the gap by drawing on the dynamic capability perspective. Based on the qualitative data collected from 35 interviews with 10 companies in China, they develop a processual model and unveil how these companies employ dynamic capabilities (i.e., sensing, seizing, and transforming), complemented by ordinary capabilities to enact, manage, and implement business model adaptation. This study provides novel insights into a theoretical issue of business model adaptation for information technology firms and managerial implications while using an adaptive business model innovation strategy.
\end{abstract}

\section{KEYWORDS}

Business Model Adaptation, Dynamic Capabilities, High-Velocity Market, Processual Model, Small and MediumSized Information Technology Firms

\section{INTRODUCTION}

A business model articulates the logic, the data and other evidence that support a value proposition for the customer, and a viable structure of revenues and costs for the enterprise delivering that value (Teece, 2010, p. 179). Prior research in the business model (BM) literature primarily focuses on business model innovation (e.g., Amit \& Zott, 2012; Foss \& Saebi, 2018; Spieth, Schneckenberg, \& Ricart, 2014); however, the understanding of business model adaptation (BMA) remains equivocal (Saebi, Lien, \& Foss, 2017; Sarta, Durand, \& Vergne, 2020). For example, there is an on-going debate about how firms adapt their business model in response to discontinuities and disruptions of external environments. Scholars have called for further research on business model adaptation (e.g. Foss \& Saebi, 2018; Massa, Tucci, \& Afuah, 2017; Spieth, Schneckenberg, \& Matzler, 2016; To, $\mathrm{Au}, \&$ Kan, 2019). 
In this study, the authors address the knowledge gap by focusing on small and medium-sized information technology (IT) firms in high-velocity business environments. First, the rapid evolution of information, computer and telecommunication technologies often challenges the existing business models and forces firms to adapt (Loon \& Chik, 2019; To et al., 2019). Second, high-velocity business environments are characterised as markets with blurred boundaries, unclear business models, and ambiguous and shifting market players i.e. buyers, suppliers, competitors, complementors (Wirtz, Mathieu, \& Schilke, 2007). In a high-velocity business environment whereby competition, technologies, government policies, and consumers' attitudes are highly uncertain, few competitive advantages can last (Liu, Ndubisi, Liu, \& Barrane, 2020; Wirtz et al., 2007), which intensifies the need and difficulty for firms to adapt their business models.

Small and medium-sized IT firms are particularly vulnerable to high-velocity environments given their limited financial and human resources with which to respond (Vargo \& Seville, 2011). It is, therefore, critical for them to develop their capabilities to innovate and adapt their business models to achieve better synchronicity with their business environments in the face of threats and opportunities. This study is concerned with this prominent issue and seeks to answer this question: how do small and medium-sized IT firms in high-velocity business environments manage their BMA? Specifically, the authors draw on dynamic capability as the underpinning theoretical perspective (Teece, 2010) to address the question. Through examining the process of the BMA of small and medium-sized IT firms, the authors aim to extend the understanding of business model literature by identifying the key dynamic capabilities that shape and determine the process of BMA, and provide business practitioners with insights into enacting, managing and implementing their BMA.

\section{LITERATURE REVIEW}

\subsection{Business Models, Business Model Innovation and Business Model Adaptation}

A business model has become an important unit and means of analysis in management research (e.g. DaSilva \& Trkman, 2014; Saebi et al., 2017; Spieth et al., 2014). Prior research on business models has been conducted from different theoretical lenses e.g. strategy. For example, from a strategic agility perspective, Battistella, De Toni, De Zan, and Pessot (2017) identify three macro-capabilities that enable the renewal of the business model: strategy innovation, resource capitalisation and networking. Studies on business models have also been extended to other non-business contexts, such as business model research for universities (Miller, McAdam, \& McAdam, 2018), healthcare (Brady \& Saranga, 2013; Winterhalter, Zeschky, Neumann, \& Gassmann, 2017), the music industry (Gamble, Brennan, \& McAdam, 2017) and social enterprises (Battistella et al., 2017; Spieth, Schneider, Clauß, \& Eichenberg, 2019).

Researchers are increasingly paying attention to business model innovation, including the prerequisites of conducting business model innovation (e.g. Kranz, Hanelt, \& Kolbe, 2016; To et al., 2019); the elements and processes of business model innovation (e.g. Chesbrough, 2010; Demil \& Lecocq, 2010; Hacklin, Björkdahl, \& Wallin, 2018); and the effects of business model innovation (e.g. Zott, Amit, \& Massa, 2011). These studies of business model innovation reflect that firms engage in innovation activities in response to the demands of the internal and external environments (Saebi et al., 2017).

Scholars have also suggested that a systematic understanding of the processes through which the firms adapt their business models can be necessary but is relatively absent from extant literature (e.g. Cozzolino, Verona, \& Rothaermel, 2018; Saebi et al., 2017). BMA has been defined as "the process by which management actively aligns the firm's business model to a changing environment" (Saebi et al., 2017, p. 569). As a process for aligning a firm's business model to a changing environment, BMA is often motivated by the need to fit in with a changing environment. 
Although existing BMA research has identified some subcomponents of the business model construct, many of the studies are divided on whether internal factors (e.g. resources) or external factors (e.g. perceived threats) are more likely to motivate BMA. For instance, Andries and Debackere (2006) claim that later-acquired resources are the enablers for BMA in new technology-based ventures. Saebi et al. (2017) further examine the key BMA drivers, including technological and market-related forces, external threats and a firm's strategic orientation towards market development. However, this line of research has focused little attention on the internal process of BMA management and the impact of external business environments.

\subsection{A Dynamic Capability Perspective of Business Model Adaptation}

Dynamic capability is defined by Teece, Pisano, and Shuen (1997, p. 516) as “a firm's ability to integrate, build, and reconfigure internal and external competencies to address rapidly changing environments". The literature on dynamic capability has disaggregated it into the sub-capacities of sensing opportunities and threats, seizing opportunities, and transforming resources (Teece, 2007, 2012). Specifically, sensing capacity involves processes such as gathering and screening information and technology relating to new business models; seizing capacity includes a company's skills in delineating customer solutions and designing a business model; and transforming capacity involves continuous renewal to achieve sustained growth. These sensing, seizing and transforming capabilities are viewed as the highest-order dynamic capabilities, and top management would do well to focus more on these because they are most relevant for the innovation and selection of business models (Teece, 2018).

Extant research on dynamic capability has shown some inconsistencies (Di Stefano, Peteraf, \& Verona, 2010; Li \& Liu, 2014). Scholars argue that there is a lack of accord around the effects of dynamic capabilities. Some scholars suggest that dynamic capabilities are vital to firms' competitive advantages (Ambrosini, Bowman, \& Collier, 2009; Teece, 2014), while other researchers argue that the role of dynamic capabilities could be limited (Zott \& Amit, 2007) and indirect (Wang \& Ahmed, 2007).

Considering these ongoing debates and inconsistencies in the role of dynamic capability, the dynamic capability perspective is selected as a suitable theoretical foundation. Firstly, the dynamic capability perspective offers a useful lens with which to capture the behind-the-scenes BMA process for firms operating in a high-velocity environment (Sapienza, Autio, George, \& Zahra, 2006). According to the definition of dynamic capabilities (Teece et al., 1997), dynamic capabilities are particularly relevant to firms when facing a rapidly changing environment. Research on environmental dynamism also shows that when the level of environmental volatility is high, the role played by dynamic capabilities becomes more salient to secure competitive advantage, because turbulence in the market might force companies to perform frequent and complex changes (Barreto, 2010). Dynamic capabilities could be developed when managers perceive the environment to be highly dynamic and complex. Therefore, dynamic capabilities might be essential for securing competitive advantages within higher levels of environmental volatility and can be particularly relevant for exploring the BMA process when firms are embedded in a high-velocity environment.

Secondly, the dynamic capability perspective is suitable for this research because of the type of firms studied. Prior research has suggested the relevance of dynamic capabilities to SMEs (Døving \& Gooderham, 2008) because SMEs operate with relatively fewer resources than their larger counterparts and are more vulnerable to the changing demands of a high-velocity environment. Researchers focus specifically on small and medium-sized IT firms as these firms must continuously adapt to dynamic market environments, and dynamic capabilities can help them to go beyond resource deficiency, through resource transformation, and onto reconfiguration (Peters, Gudergan, \& Booth, 2019; Weerawardena, Mort, \& Liesch, 2019). This in turn enables them to align their business models with changing customer needs (Teece, 2018). 
Extant research has further emphasised that there is little knowledge of how SMEs use dynamic capabilities to adapt their business models in highly volatile markets e.g. the functions of dynamic capabilities and when SMEs should utilise these capabilities for the BMA process. The authors intend to address this gap, which is vital to understanding how small and medium-sized IT firms deploy and leverage different sets of dynamic capabilities through their BMA process.

\section{METHODOLOGY}

\subsection{Sampling and Data Collection}

The study is to unveil the BMA process that remains largely a kind of black box in literature. To fit the exploratory nature of this study (Edmondson \& McManus, 2007), a qualitative method was selected because it allows the researcher to understand complex mechanisms and phenomena (Maxwell, 2012). Specifically, the authors used a case study to address the research question. The case study, according to Piekkari, Welch, and Paavilainen (2009, p. 569), is a "research strategy that examines, through the use of a variety of data sources, a phenomenon in its naturalistic context, with the purpose of confronting theory with the empirical world". It can, through producing a great level of details, help us make sense of why and how firms' behaviour relating to BMA takes place, as well as explore new theoretical explanations (Eisenhardt, 1989; Welch, Piekkari, Plakoyiannaki, \& Paavilainen-Mäntymäki, 2011; Yin, 2003).

The authors chose to focus on small and medium-sized IT firms in China to examine the process of BMA. China is one of the world's most fast-paced, high-velocity markets (Li, Easterby-Smith, \& Hong, 2019) whereby many of its sectors have demonstrated rapid growth over the past 30 years, especially the IT software industry with an average annual growth rate of over 25 percent (Garnaut, Song, \& Fang, 2018). China as a transition economy has also been undergoing large-scale economic and institutional change since it began its reforming policies (Jiang, Gong, Wang, \& Kimble, 2016), which not only provide plenty of opportunities for Chinese firms but also create additional pressure for them to adapt in order to survive and grow. Thus, in line with previous scholars (Li, Su, Zhang, \& Mao, 2018; Li et al., 2019), the authors consider that SMEs in China's IT sector provides an ideal context for this study.

A multiple-case design is undertaken because it allows within- and cross-case analysis, through which more compelling and robust findings can be generated (Yin, 2009). To identify potential cases, the authors approached the Zhong Guan Cun Software Park in China's capital, Beijing. The Park was established in 1999 by the government to nurture the domestic IT industry and showcase the nation's success in the high-tech sector. The authors requested assistance from the Park's management team and with their help, a list of companies registered in the Park with no more than 300 full-time employees was compiled. While the official definition of small and medium-sized IT firms in China is any firm with either an annual turnover of less than 100 million or fewer than 300 employees (NBSC, 2011), the latter was used in this study because the financial figure was often unavailable or inaccurate. The list contains approximately 150 companies.

The authors contacted those companies over the phone and attempted to reach the CEOs or the General Managers to briefly introduce them about the project. Those who expressed an interest were asked whether their companies had experienced any type of BMA in recent 3-5 years. In this way, the study followed a criterion sampling technique that involves studying cases that "meet some predetermined criterion of importance" (Suri, 2011, p. 69). Following previous scholarly work, the authors explained business model as the design or architecture of the firm's value creation, delivery and capture, and described BMA flexibly as a new or different way of operating the business in response to changes in the external environment (Cozzolino et al., 2018; Teece, 2010). Next, the authors sought the managers' collaboration in the study and ensured that the contents of the interviews would be kept strictly confidential and anonymous. However, despite endorsement from the Park's management 
Table 1. Case stuy firms and their business models

\begin{tabular}{|c|c|c|c|c|c|c|c|}
\hline Company & $\begin{array}{l}\text { Date } \\
\text { of est. }\end{array}$ & $\begin{array}{l}\text { No. of } \\
\text { employees }\end{array}$ & Sector & Products & Start-up BMI & Current BMI & Future BM \\
\hline A-SBUI & 2001 & 97 & $\begin{array}{l}\text { Rvilway } \\
\text { automation }\end{array}$ & $\begin{array}{l}\text { Technologically advanced signalling } \\
\text { equipment and value-added service }\end{array}$ & $\begin{array}{l}\text { Small } \\
\text { workgroup }\end{array}$ & Product model & $\begin{array}{l}\text { An integration of product model. } \\
\text { Bait-Hook model, servitisation }\end{array}$ \\
\hline A-SBU2 & 2009 & 117 & $\begin{array}{l}\text { Railway } \\
\text { automation }\end{array}$ & & $R \& D$ project & Product model & $\begin{array}{l}\text { An integration of product model, } \\
\text { Bait-Hook model, servitisation }\end{array}$ \\
\hline B & 2007 & 50 & $\begin{array}{l}\text { Artificial } \\
\text { intelligence }\end{array}$ & $\begin{array}{l}\text { Customised software products and service, } \\
\text { software as a service (SaaS) for SMEs }\end{array}$ & Project model & License model & Licence and SaaS \\
\hline c & 2002 & $100+$ & $\begin{array}{l}\text { Mass market } \\
\text { cosmetics }\end{array}$ & $\begin{array}{l}\text { Marketing solutions for cosmetics } \\
\text { business customers }\end{array}$ & $\begin{array}{l}\text { Advertising } \\
\text { agent }\end{array}$ & $\begin{array}{l}\text { Print media and } \\
\text { website }\end{array}$ & Full media \\
\hline D & 2014 & 10 & Shared economy & Job matchmaking e-platform & E-broker & E-broker & $\begin{array}{l}\text { E-broker financed by a small-scale } \\
\text { Saas }\end{array}$ \\
\hline $\mathbf{E}$ & 2014 & $10+$ & $\begin{array}{l}\text { Business } \\
\text { intelligence for } \\
\text { FMCG }\end{array}$ & Castomised digital marketing platform & Consulting & $\mathrm{CDM}^{3}$ & CDM and Saas \\
\hline $\mathbf{F}$ & 2013 & 12 & Call centre ICT & $\begin{array}{l}\text { call centre products and system integration } \\
\text { and after-sale services }\end{array}$ & $\begin{array}{l}\text { Product selling } \\
\text { model }\end{array}$ & $\begin{array}{l}\text { Licence model; } \\
\text { customisation; } \\
\text { servitisation }\end{array}$ & $\begin{array}{l}\text { A mix of licence model. SanS, and } \\
\text { system integation service }\end{array}$ \\
\hline G & 2009 & 280 & Rail signalling & $\begin{array}{l}\text { Technologically advanced train control } \\
\text { system }\end{array}$ & $\begin{array}{l}\text { Small } \\
\text { workgroup }\end{array}$ & Product model & $\begin{array}{l}\text { An integration of product model and } \\
\text { servitisation. }\end{array}$ \\
\hline H & 2011 & 30-35 & Machine vision & $\begin{array}{l}\text { machine vision systems for packaging. } \\
\text { tectile, and photovoltaic fatrics; } \\
\text { customised product detection service }\end{array}$ & Project model & Project model & $\begin{array}{l}\text { An integration of product model and } \\
\text { servitisation }\end{array}$ \\
\hline I & 2012 & 70 & $\begin{array}{l}\text { Software and } \\
\text { service for } \\
\text { process industry }\end{array}$ & $\begin{array}{l}\text { 3D modelling of a digital fictory and data } \\
\text { integration service }\end{array}$ & $\begin{array}{l}\text { Intermediary } \\
\text { service }\end{array}$ & $\begin{array}{l}\text { Licence model; } \\
\text { customisation; } \\
\text { servitisation }\end{array}$ & $\begin{array}{l}\text { A mix of licence model. SaaS and } \\
\text { system integation service }\end{array}$ \\
\hline $\mathbf{J}$ & 2016 & 150 & $\begin{array}{l}\text { Professional } \\
\text { education }\end{array}$ & $\begin{array}{l}\text { Practice-based educational programme } \\
\text { solutions, including Ir sector education } \\
\text { solutions and rail transit sector education } \\
\text { solutions }\end{array}$ & Project model & $\begin{array}{l}\text { Franchised product } \\
\text { selling model }\end{array}$ & $\begin{array}{l}\text { A mix of product mode, freemium } \\
\text { and servitisation }\end{array}$ \\
\hline
\end{tabular}

office (i.e. a recommendation letter provided by the office to solicit company support), only 18 companies agreed to participate. Such a low response rate, as Plakoyiannaki, Wei, and Prashantham (2019) observed, is a common challenge faced by qualitative researchers in China.

The authors then scheduled the meetings with the companies. Only 10 were included in the study after eight withdrew due to such reasons as 'change of mind' or 'unavailability' (see Table 1 for more information on the companies). These companies, nonetheless, represent a well-balanced sample in terms of size (six with fewer than 100 employees and four with more than 100 employees) and age (five established pre-2010 and five post-2010).

Importantly, through the CEOs and/or the General Managers were initially approached, the authors further explored the possibility of interviewing other top decision-makers in each company like the Directors of Marketing and R\&D. This strategy of identifying and securing key informants who have sufficient knowledge of their businesses and can provide rich and credible insights into the research issue of the focal company, has proven to be sound in previous business model research (Zott \& Amit, 2007; Zott et al., 2011). The authors set up all the interviews as individual-based interviews to address concerns about confidentiality and so that the participants could be more open with us. This approach, according to Yin (2009) benefits qualitative case studies, especially in terms of reliability. A total of 35 interviews were conducted with the ten companies (see Table 2 for information about the interviewees).

All the interviews were semi-structured, taking place in the interviewee's office or elsewhere if the interviewee preferred. Each followed a standardised interview protocol comprising four sections, and the typical interview lasted 90 minutes. In the first section, the authors established the participants' general demographic information. In the second section, the authors asked the participants to share their understanding and awareness of the focal business model. The third section is related to the creation, development and innovation of the business model e.g. key drivers, major obstacles and other related factors. In the fourth section, the authors asked about past changes and evolution of the business model; for example, "How does the business model cope with opportunities and threats?". Note that before the data collection, two pilot interviews were conducted with professional managers in other companies to help refine the interview instrument. 
Table 2. Participant information

\begin{tabular}{|c|c|c|c|c|c|}
\hline Participant & Age group & Position & Tenure of current role & Tenure in company & Time of employment \\
\hline IM_A & $41-50$ & Product manager & 4 & 9 & 18 \\
\hline $2 \mathrm{M}_{\mathrm{A}}$ & $51-60$ & Disector & 4 & 16 & 20 \\
\hline 3M_A & $41-50$ & Deputy chief engineer & 8 & 16 & 23 \\
\hline 4M_A & $41-50$ & Vice chairman & 16 & 16 & 26 \\
\hline $5 \mathrm{M}$ & $31-40$ & Product manager & 6 & 10 & 10 \\
\hline M_A & $41-50$ & CEO & 5 & 9 & 25 \\
\hline 7M_A & $31-40$ & Product manager & 2 & 12 & 12 \\
\hline 8M_A & $31-40$ & Technical support manager & 2 & 12.5 & 14.5 \\
\hline $9 \mathrm{M}$ & $41-50$ & Chief enginet & 4 & 125 & 23 \\
\hline $10 \bar{M}_{B}$ & $41-50$ & CEO & 10 & 26 & 26 \\
\hline 11M_B & $41-50$ & Vice general manager & 8 & 23 & 23 \\
\hline $12 \mathrm{M}-\mathrm{C}$ & $41-50$ & Chaiman & 15 & 25 & 25 \\
\hline $13 \mathrm{M}_{-} \mathrm{C}$ & $41-50$ & CEO & 12 & 25 & 25 \\
\hline 14M_D & $31-40$ & CEO & 3 & 3 & 8 \\
\hline 15M_E & $41-50$ & CEO & 3 & 3 & 20 \\
\hline 16_E & $31-40$ & HR manager & 1 & 1 & 10 \\
\hline $17 \mathrm{~F}_{\mathrm{E}}$ & $41-50$ & CFO & 3 & 3 & 10 \\
\hline 18M_F & $41-50$ & CEO & 5 & 5 & 17 \\
\hline $19 \mathrm{MF}$ & $41-50$ & Product manager & 5 & 5 & 16 \\
\hline $20 \mathrm{MF}$ & $41-50$ & Product manager & 5 & 5 & 17 \\
\hline 21M_F & $35-40$ & Product manager & 5 & 5 & 11 \\
\hline $22 \mathrm{M}$ & $31-40$ & Safety and quality assurance department deputy manager & 2 & 10 & 12 \\
\hline $23 \mathrm{MG}$ & $31-40$ & Product manager & 3 & 9 & 12 \\
\hline 24 M_G & $31-40$ & Safety manager & 4 & 4 & 10 \\
\hline 25M_H & $41-50$ & Product manager & 7 & 7 & 18 \\
\hline $26 \mathrm{M}$ & $41-50$ & CEO & 7 & 7 & 21 \\
\hline $27 \mathrm{M}$ & $41-50$ & R\&D director & 7 & 7 & 20 \\
\hline $28 \mathrm{MI}$ & $41-50$ & Prochut manager & 4 & 5 & 18 \\
\hline $29 \mathrm{M}$ & $41-50$ & CEO & 6 & 6 & 20 \\
\hline $30 \mathrm{M}$ & $51-60$ & Vice general manager & 6 & 6 & 22 \\
\hline 31M_I & $41-50$ & Vice general manager & 6 & 6 & 17 \\
\hline $32 \mathrm{M}$ & $41-50$ & Product manager & 4 & 4 & 15 \\
\hline $33 \mathrm{M}$ & 41.50 & CEO & 2 & 2 & 15 \\
\hline $34 \mathrm{M} J$ & $31-40$ & Vice general manager & 2 & 2 & 8 \\
\hline $35 \mathrm{MJ}$ & $41-50$ & Vice general manager & 2 & 2 & 20 \\
\hline
\end{tabular}

All interviews were recorded, transcribed in Chinese, and then translated into English using a standard back-translation procedure (Schaffer \& Riordan, 2003). The researchers as native Chinese speakers were very familiar with the local context, which was helpful for the study in terms of understanding the focal phenomenon, exploring relationships and excluding alternative explanations (Plakoyiannaki et al., 2019). Also, during the interview, if there was no equivalent concept in the local language, the authors were able to use additional words to convey the desired meaning. It is an effective solution to help ensure construct validity (Plakoyiannaki et al., 2019). The authors also requested relevant company documents (e.g. reports, meeting notes, media releases) as evidence whenever possible and constantly sought to cross-check the facts and statements mentioned by one interviewee with those mentioned by another from the same company. Such triangulation using multiple data sources, according to Maxwell (2012) and Yin (2009), enhances the data validity of the study.

\subsection{Data Analysis}

Despite the relatively small sample, the study produced rich data. Analysis of the data was performed by the researchers and it fell into three stages described below. First, the authors began by developing a narrative account for each case company (Eisenhardt, 1989) through establishing a chronology. The chronology was made up of key events and facts that shaped the adaptation process of the focal business model. It helped us to maintain focus during the analysis. Second, in analysing the interview data, the authors looked for managers' perceptions of how and why the business model was adapted over time. The study, thus, emphasises what Tsang (2013) described as a contextualized explanation, that is, the intention to advance the existing theory (i.e. dynamic capability) by offering contextualized insights. The authors used the rich information from the managers to establish themes, map the extant theory and ultimately identify possible theory extensions (Paul, Parthasarathy, \& Gupta, 2017).

Specifically, following previous BMA research (Zhao, Von Delft, Morgan-Thomas, \& Buck, 2019), the authors relied on two widely accepted approaches to conceptualization, value-based perspective and activity system-based perspective, to shape the analysis and structure the findings. 
The value-based perspective was suggested by Teece (2010). It defines a business model with three components: value proposition, value creation and delivery, and value capture. Specifically, value proposition concerns what the firm will deliver to its customers, such as the offering, the target customer and the basic strategy (Cepeda \& Vera, 2007); value creation and delivery refer to how the firm will create and deliver that value to its customers; and value capture focuses on how the firm generates revenue and profit (Teece, 2010). The activity system perspective was suggested by Zott and Amit (2010). It depicts a business model as a system of three interdependent activities designed to create and deliver value: content, structure, and governance. Here, content refers to the selection of activities, structure describes the sequence of the activities, and governance refers to who performs the activities.

During the third stage, the authors collated the findings from both the interviews and supplementary sources as mentioned earlier for triangulation. This also provided us with a more comprehensive picture of the case. The software NVivo 12 was used to assist the data analysis. The data was stored carefully and only accessible by the two researchers for reasons of confidentiality. Also note that for the interviews, the two authors first analysed the data independently, and then cross-checked the coding for consistency. If a quote was coded into different codes or theoretical categories, the authors re-coded it based upon the consensus. This approach increased the validity of the findings. Subsequently, the authors cross-case examined the patterns and processes of BMA to find out how different concepts, categories and relationships fit together in a coherent manner. Additionally, the authors also shared the preliminary findings with several interviewed managers and incorporated their feedback into the final framework. Table 3 details the structure of the data analysis including categories, subcategories, and their corresponding aggregate dimensions.

\section{FINDINGS AND DISCUSSION}

The researchers present the findings on the identified conceptual framework, then consider the key elements in the process (e.g. value proposition and activity system content) and then follow these with the findings on dynamic capabilities and ordinary capabilities, which, when combined, facilitate BMA. Two widely accepted perspectives, including the value-based perspective suggested by Teece (2010) and the activity system-based perspective from Zott and Amit (2010), were used to shape the BMA analysis and structure the findings and provide a more complete picture of the heuristic logic that connects the business model characteristics of small and medium-sized IT firms with the realisation of firm capability value (e.g. Zhao et al., 2019).

\subsection{A Process Model of Business Model Adaptation}

Figure 1 depicts the BMA process of case firms and the role of dynamic capabilities involved in the BMA process. Small and medium-sized IT firms had initially sensed the changes that had occurred in the market, including the threat of disruptive technology to survival, the opportunities of underutilised data, and the opportunities of shifts in customers' needs. In response, they decided to counteract the threats or capture the opportunities by adjusting the business model component of their value propositions and activity system content. Seizing capabilities were then deployed to make further adjustments to value creation and delivery, value capture, activity system structure, and activity system governance, with the ultimate goal of managing the business model components and harvesting value. Subsequently, ordinary capabilities at a managerial level were deployed to ensure effective and efficient implementation (Teece, 2018). Ultimately these small and medium-sized IT firms achieved their outcomes in relation to know-how, relationship assets, data assets, and/or performance.

\subsection{Findings From The Value-Based Perspective}

The case firms have tried to diversify their value propositions to cover more customer segments and provide a more comprehensive service to their end customers. In line with the findings of previous 
Table 3. Description of coding categories

\begin{tabular}{|c|c|c|c|}
\hline Coding Category & Description & Example codes & Representative quotations \\
\hline Sensing capabilities & $\begin{array}{l}\text { Activities and instances in which the } \\
\text { interviewees discuss how to leam and to } \\
\text { sense, filter, shape and calibrate } \\
\text { environmental information }\end{array}$ & $\begin{array}{l}\text { 'sense', 'feel', 'aware of, 'good } \\
\text { chance', 'identify', 'opportunity', } \\
\text { 'new' }\end{array}$ & $\begin{array}{l}\text { "We sensed the threat of SaaS and initiated a scale-up } \\
\text { strategy." } \\
\text { "We believed transforming to new media and } \\
\text { e-commerce is inevitable and investing in new } \\
\text { technology is necessary." }\end{array}$ \\
\hline Seizing capabilities & $\begin{array}{l}\text { Activities and instances in which the } \\
\text { interviewees describe how to facilitate the } \\
\text { development of strategic decisions e.g new } \\
\text { product, processes and service from the } \\
\text { 'sensed' opportunities for their business } \\
\text { model adaptation }\end{array}$ & $\begin{array}{l}\text { 'seize', 'grasp', 'address', 'capture', } \\
\text { 'reshape', 'change', 'adapt', 'remodel' }\end{array}$ & $\begin{array}{l}\text { "Our company made the change from license model } \\
\text { to a mix of license model, freemium, and long tail } \\
\text { model." } \\
\text { "We shaped a customer driven organisation so as to } \\
\text { closely cooperate with customers and tap customer } \\
\text { innovation." }\end{array}$ \\
\hline Ordinary capabilities & $\begin{array}{l}\text { Activities and instances in which the } \\
\text { interviewees discuss how to ensure the } \\
\text { effective and efficient implementation at } \\
\text { managerial levels }\end{array}$ & $\begin{array}{l}\text { 'implementation', 'daily', 'operations', } \\
\text { 'administration', 'facilitate', } \\
\text { 'coordinate' }\end{array}$ & $\begin{array}{l}\text { "We try our best to implement the routine activities } \\
\text { and administration effectively and efficiently." } \\
\text { "We have to ensure the coordination and alignment } \\
\text { between the teams and streamline the process." }\end{array}$ \\
\hline Environmental dynamism & $\begin{array}{l}\text { Activities and instances in which the } \\
\text { interviewees describe the emerging business } \\
\text { challenges and opportunities in their business } \\
\text { environment }\end{array}$ & $\begin{array}{l}\text { 'clange', 'innovation', 'new', 'threat', } \\
\text { "customer needs', 'new policy', 'new } \\
\text { regulations' }\end{array}$ & $\begin{array}{l}\text { "We knew the threat of survivability and crafted a } \\
\text { market orientation strategy." } \\
\text { "Saas and data asset are the new focus, and } \\
\text { customers have innovative ideas, and more industrial } \\
\text { needs are stimulated by digital technology." } \\
\text { "Our major customers are subsidiaries of SOE, } \\
\text { whose procurement decision is restrained by the } \\
\text { changing government policies and rules, such as } \\
\text { financial rules." }\end{array}$ \\
\hline
\end{tabular}

studies e.g. Landau, Karna, and Sailer (2016); Saebi et al. (2017), the findings show that changing its value proposition is a firm's response to external threats and/or opportunities in high-velocity markets. The case firms are reducing the distance to their end customers and serving them more directly. Changing digital technology has increased the need for always-on service. In response, case firms are adjusting their value propositions to meet the needs of a larger customer base by embracing new technology, such as 3D modelling, big-data and app platforms.

Case firms have adopted co-creation and co-evolution, as well as in-house innovation, as major ways to create and deliver value for their customers and end-users. Co-creation and co-evolution in value creation and delivery are facilitated through in-house innovation that is often triggered by emerging digital technologies, as suggested by Cozzolino et al. (2018). The researchers find that the key to successful value creation is for small and medium-sized IT firms to be actors within the value network, so their firms can cooperate closely and co-evolve with many online ecosystems, such as open-source forums and entrepreneur forums, etc.

Case study firms have diversified their value capture logic by shifting from single models to mixed models, which is similar to the findings of previous studies e.g. Hacklin et al. (2018). Other changes in value capture logic are manifested by embracing the long-tail model, moving from a conventional product model to an internet-based online service model, and adopting a multi-sided model to link manufacturers, dealers, and retailers. The value capture details of the case study firms are summarised in Table 4 . Besides, Table 5 presents representative quotes that are organised according to the key factors discussed.

\subsection{Findings From An Activity System Perspective}

In terms of activity system content, demand-side value creation and capture emerge as components of a core theme that lays the foundation e.g. for know-how generation, smart modelling, and intelligent service design. The adjustment is a response to external changes and is driven by the internal processes that firms use to identify customer innovation, tap complementary innovation, and/or direct internal R\&D and select new technologies (Amit \& Zott, 2012; Zott \& Amit, 2010). Established firms and start-ups tend to use different models to grow their businesses in the activity system structure. Established firms have extra resources with which to fund and staff the new activities, which shows that unabsorbed slack (e.g. financial resources and know-how) could be a reason for them to select the use of the incubator model for business model innovation, which is in line with a previous study (e.g. 


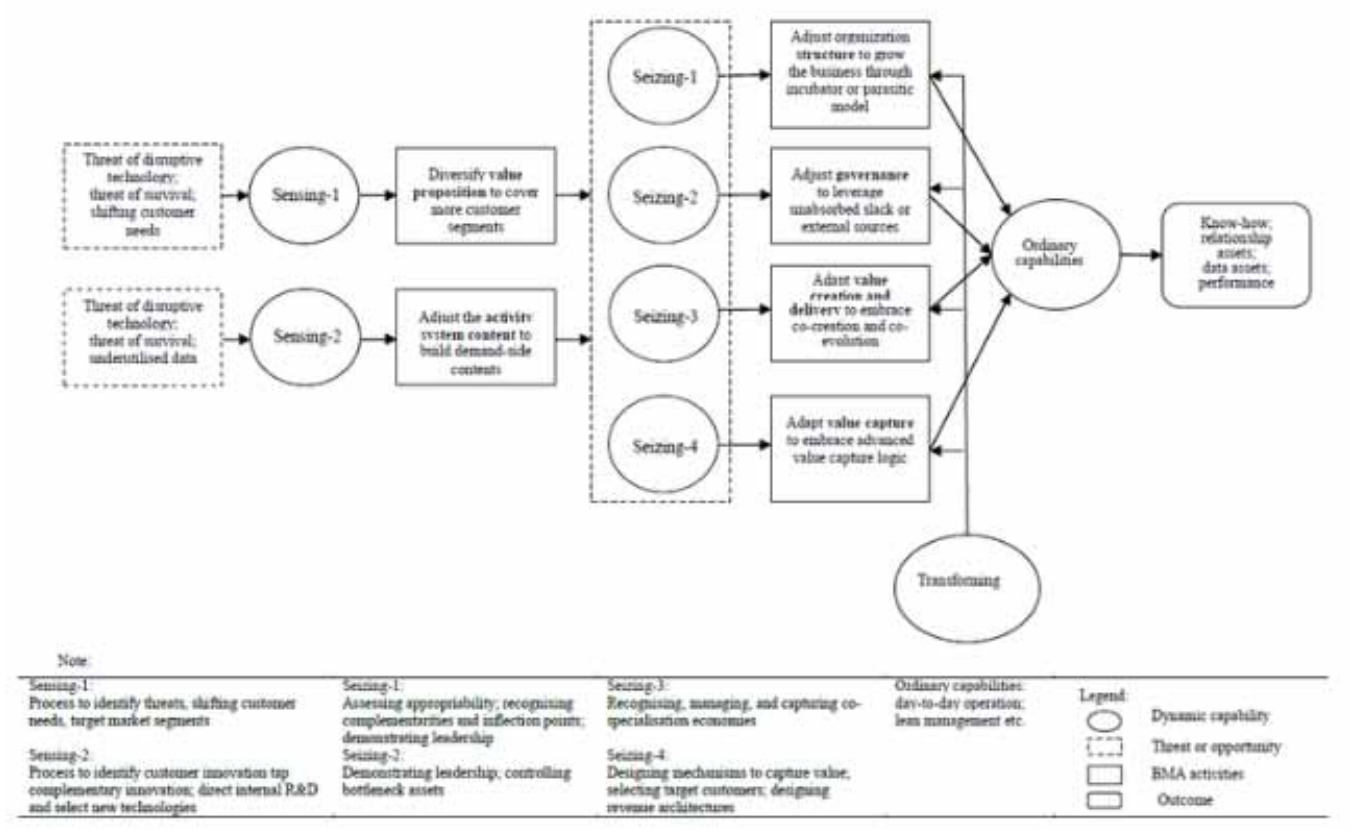

Andries \& Debackere, 2006). By contrast, start-ups that lack unabsorbed slack must temporarily use a parasitic model to finance their target business model and rely on venture capital for future growth.

\section{RESEARCH IMPLICATIONS}

\subsection{Theoretical Implications}

The research examines the BMA of small and medium-sized IT firms in the high-velocity business market and responds to the call for further research on business model adaptation (e.g. Foss \& Saebi, 2018; Massa et al., 2017; Saebi et al., 2017; To et al., 2019). In doing so, the researchers explore the BMA processes and mechanisms inherent in small and medium-sized IT firms drawing on a dynamic capability perspective.

The study makes three key contributions. Firstly, the study contributes to the BMA literature by exploring the 'black box' of the BMA process from a dynamic capability perspective. Through linking dynamic capabilities to related BMA activities, small and medium-sized IT firms' dynamic capabilities act as internal drivers to cope with external adaptation threats and convert opportunities into strategic assets and improved performance. The findings suggest a radical approach to the development of dynamic capabilities within firms and expand the scope of the extant dynamic capabilities literature, which generally suggests an incremental approach.

Secondly, the study contributes to the BMA literature by developing a processual model that is built on the complex interactions between key components of small and medium-sized IT firms' business models and related dynamic capabilities. This research advances the understanding of the rationale and processes of strategic decision-making made by IT SME managers when facing external challenges e.g. digital disruptions. In addition, insights are provided on how new thoughts (e.g. demand-side thinking) that have emerged in the high-velocity market are deployed in order to adapt business models within complex and uncertain contexts. 
Table 4. Business model adaption- value capture

\begin{tabular}{|c|c|c|c|}
\hline Firns & & Value capture logic & Representative quotations \\
\hline \multirow[t]{2}{*}{ A } & Present & $\begin{array}{l}\text { Sales of products under contract or through } \\
\text { strategic alliance agreement. }\end{array}$ & $\begin{array}{l}\text { Our company has taken a controlling position within the niche segment, performing core } \\
\text { activities, building up and sustaining a network of reliable partuers. }\end{array}$ \\
\hline & Future & $\begin{array}{l}\text { As above, plus boost sales of products by valued-added big data } \\
\text { service, and subscription of licence service. }\end{array}$ & $\begin{array}{l}\text { "In the future, we intend to attract high talents and reliable partners to support the promising big } \\
\text { data service." }\end{array}$ \\
\hline \multirow[t]{2}{*}{ B } & Present & Sell licence to big customers. & "We customised sottware product and service for several big customers" \\
\hline & Future & As above, but SaaS for SMEs will be another main source of revenue. & $\begin{array}{l}\text { "We is going to design and operate a SaaS platform through leveraging the company's HR and } \\
\text { financial assets and close cooperation with key customers." }\end{array}$ \\
\hline \multirow[t]{2}{*}{ c } & Present & Multi-sided model linking manufacturers, dealers and retailers. & $\begin{array}{l}\text { "Our firm belps cosmetics business customers, including manufacturers, dealers, and retailers, to } \\
\text { grow business and to inprove berand awareness throuph our accurate and in-depth business } \\
\text { service" }\end{array}$ \\
\hline & Future & Transform to an intemet enterprise, develop $\mathrm{B} 2 \mathrm{C}$ and $\mathrm{O} 2 \mathrm{O}$. & $\begin{array}{l}\text { "We aim to take a leading position in cosmetics media industry. Differentiation and downstream } \\
\text { extension are our next strategic objectuves." }\end{array}$ \\
\hline \multirow[t]{2}{*}{ D } & Present & $\begin{array}{l}\text { Sales of service with a multi-sided model that brings employers and job } \\
\text { seekers together. }\end{array}$ & "We run a job matchmaking e-platform at the moment." \\
\hline & Future & $\begin{array}{l}\text { A multi-sided model empowered by flow fans econony and sales of } \\
\text { Saas by subscription. }\end{array}$ & $\begin{array}{l}\text { We intend to accumnlate valuable data, to grow value network, and to shape core conpetence } \\
\text { through trial and error." }\end{array}$ \\
\hline \multirow[t]{3}{*}{ E } & Present & $\begin{array}{l}\text { Anmual contractual service package (basic service and customised } \\
\text { service). }\end{array}$ & $\begin{array}{l}\text { "We grow the business through a customer dniven organization. At present, we design and operate } \\
\text { "we-medaa' and CDM for big business customers." }\end{array}$ \\
\hline & Future & As above, plus SaaS for SMEs in FMCG industry. & $\begin{array}{l}\text { "Our firm targets at operating a typical SaaS model and providing service for FMCG SMEs in the } \\
\text { near futuse." }\end{array}$ \\
\hline & Present & Sales of products under contract or by strategic alliance agreement. & $\begin{array}{l}\text { "The main business activities of our fim are to design, test, and maintain the softwase products; } \\
\text { provide system solutions and on-site service." }\end{array}$ \\
\hline \multirow{2}{*}{$F$} & Future & $\begin{array}{l}\text { As above, plus sales of service by subscription mode and freemium } \\
\text { model to capture value through conmunatiation charges. }\end{array}$ & $\begin{array}{l}\text { "In the future customer experience is enhanced through offering more function options, ie. } \\
\text { freernium and generalised service for SME customers and customised service for big companies." }\end{array}$ \\
\hline & Present & Sales of products under contract or by strategic alliance agreement. & $\begin{array}{l}\text { "Currently we design, assembly, and test the products. We also run a small-scale manuficturing. } \\
\text { installation, commissioning, tral operation and after-sales service." }\end{array}$ \\
\hline \multirow{2}{*}{$G$} & Future & $\begin{array}{l}\text { As above, plus leasing model (similar to Rolls-Royce's 'power-by-the- } \\
\text { bour' model) and sales of training and consultrant service. }\end{array}$ & "We'd like to have more add-value service, such as operation management, training, and leasing " \\
\hline & Present & Sales of products under contract. & "We sell our product in a sale and purchase agreement". \\
\hline \multirow[t]{2}{*}{$H$} & Future & As above, plus sales of value-added service by SaaS. & $\begin{array}{l}\text { We will more focus on belping customer improve productivity, reduce cost, and create more } \\
\text { sales of value-add services by SaaS." }\end{array}$ \\
\hline & Present & Sales of products and service under contract. & "We currently rely on a license model." \\
\hline \multirow[t]{2}{*}{$I$} & Future & As above, plus sales of service by the subscription model. & "In the future, we would like to shitt towards a franchised product selling mode." \\
\hline & Present & Sales of educational programme solutions under contract. & "We provide educational programme solutions under contract." \\
\hline$J$ & Future & $\begin{array}{l}\text { As above, plus sales from being a general contractor of educational } \\
\text { services. }\end{array}$ & "We ase working towards a mix of product mode, Freemium, and servitization" \\
\hline
\end{tabular}

Table 5. Representative quotes of case studies

\begin{tabular}{|c|c|c|}
\hline & Key factors & Representative quotations \\
\hline \multirow[t]{6}{*}{ Value proposition } & Serve end customers & $\begin{array}{l}\text {-Our end users are calling for more nimble service of diagnostics and prognostics, so we decide to provide big data- } \\
\text { based service for them" (Participant 1M_A) }\end{array}$ \\
\hline & & $\begin{array}{l}\text { We think that we should approach our end customers as close as possible, and serve them directly and intimately." } \\
\text { (Participant 2M_A) }\end{array}$ \\
\hline & Customised products & $\begin{array}{l}\text { "Our firm has a clear strategy to sell service to big business customers first and then extend to small firms." } \\
\text { (Participant 15M_E) }\end{array}$ \\
\hline & & $\begin{array}{l}\text { "Our products are extended from customisation to Reneralisation, from several high-end customers to mumerous } \\
\text { medium and low-end customers." (Participant 11M_B) }\end{array}$ \\
\hline & Value-added service & $\begin{array}{l}\text { We attempted to provide more add-value service, such as operation management, training and leasing." (Participant } \\
\text { 23M_G) }\end{array}$ \\
\hline & & $\begin{array}{l}\text {-Our R\&D orientation strategy are infuenced by increasing need of added-value service of diagnostics and } \\
\text { prognostics by end customers." (Participant } 6 \mathrm{M} \text { _A) }\end{array}$ \\
\hline \multirow[t]{3}{*}{$\begin{array}{l}\text { Value creation and } \\
\text { delivery }\end{array}$} & Co-creation with business customers & $\begin{array}{l}\text { We actually don't know how the customers use their data. Working closely with customers is the basis of in-depth } \\
\text { integrating AI technique with industrial needs. .. Then we can define new service functions based on the } \\
\text { commonalities between different applications and contexts" (Participant 9M_B) }\end{array}$ \\
\hline & & $\begin{array}{l}\text {-Our company eneages co-creation with our business customers through in-depth integrating AI with our industrial } \\
\text { needs." (Participant 11M_B) }\end{array}$ \\
\hline & Co-evolution with stakeholders & $\begin{array}{l}\text { We maintain close cooperation with many communities, such as open-source forum, we-chat community, interest } \\
\text { groups, entrepreneur forum, etc." (Participant 14M_D). }\end{array}$ \\
\hline \multirow[t]{6}{*}{ Value capture } & Embrace Long-tail & $\begin{array}{l}\text { Revenue will decrease shortly when the SasS model is initiate. But the long tail effect may appear later, and it will } \\
\text { be another main source of revenue for the company' (Participant 9M_B) }\end{array}$ \\
\hline & & $\begin{array}{l}\text { "Coaventional manufacturing industry model are increasingly infuenced by the long-tail effect." (Participant } \\
12 \mathrm{M} C \text { ) }\end{array}$ \\
\hline & Multi-sided model & $\begin{array}{l}\text { We have a multi-sided model that brings together employers and temporary job seekers... we are confident that it } \\
\text { will be empowered by flow econony and hans econonyy next year." (Participant 12M_D) }\end{array}$ \\
\hline & & $\begin{array}{l}\text { "Our company benefit from runs a multi-sided model which links our manufacture, dealers, and retailers." } \\
\text { (Participant } 13 \mathrm{M} \text { _C) }\end{array}$ \\
\hline & Shift to mixed models & $\begin{array}{l}\text { "Our sales have been boosted by add-valued big data service. We also sell our service through subscription or } \\
\text { license." (Participant 11M_B) }\end{array}$ \\
\hline & $\begin{array}{l}\text { Adjust to an intemet-based online } \\
\text { service model }\end{array}$ & $\begin{array}{l}\text { "Transforming to an Internet enterprise is an unavoidable choice for print media. Now we have a pilot e-platforms, } \\
\text { and we are trying to capture values by attracting both online and offline sales." (Participant 13M_C) }\end{array}$ \\
\hline
\end{tabular}


Thirdly, this study identifies and highlights the conditions of BMA decision making relevant to the opportunities and challenges in an embedded business environment. The researchers identify the four characteristics of the threat of disruptive technology, the threat of survival, the opportunity of underutilised data, and the opportunity of shifting customer needs as antecedents of BMA, which can foster the BMA of small and medium-sized IT firms.

\subsection{Managerial Implications}

The research has important implications for small and medium-sized IT firms in emerging markets. The findings suggest that the decision-makers in IT service provider firms should consider the role of dynamic capabilities in firms' BMA processes and, more importantly, IT firms should cultivate and then deploy their dynamic capabilities internally to manage external threats through more effective BMA. Managers of small and medium-sized IT firms can use the proposed process model to integrate their dynamic capabilities in relation to BMA activities within firms. Dynamic capabilities can act as internal drivers to cope with external threats (e.g. disruptive digital technologies) and can help convert opportunities into strategic assets and influence firms' outcomes.

\subsection{Limitations and Future Research}

The research has limitations which offer opportunities for further research. It is an exploratory study focusing more on BMA theory development rather than theory testing. Its qualitative nature and small sample size might limit the generalizability of the findings. Thus, research conducted in other sectors or contexts would be meaningful. Future research may also adopt a quantitative method to further validate the findings. A longitudinal study would be particularly useful for researchers to track whether the identified changes in value proposition and value capture have occurred and have been seized. Future research could also focus on some specific digital challenges, such as artificial intelligence (AI), as this could facilitate a further understanding of how emerging technology disruptions influence BMA and how managers respond and manage these challenges.

\section{CONCLUSION}

The research contributes to the debate on how firms' business models adapt to external environments. Drawing on dynamic capability perspectives, the authors propose a conceptual framework of BMA for small and medium IT firms in China. Case study analysis advances the literature with an insight to the interaction of external triggers (e.g. environmental threats and opportunities) and internal drivers (e.g. dynamic capabilities). The findings reveal the process of BMA from the lens of dynamic capabilities. Overall, the researchers found that dynamic capabilities play a role in facilitating the BMA process, and enable the managers of small and medium-sized IT firms to respond more effectively to external changes. 


\section{REFERENCES}

Ambrosini, V., Bowman, C., \& Collier, N. (2009). Dynamic Capabilities: An Exploration of How Firms Renew their Resource Base. British Journal of Management, 20, S9-S24. doi:10.1111/j.1467-8551.2008.00610.x

Amit, R., \&Zott, C. (2012). Creating value through business model innovation. MIT Sloan Management Review, 53(3), 41.

Andries, P., \& Debackere, K. (2006). Adaptation in new technology-based ventures: Insights at the company level. International Journal of Management Reviews, 8(2), 91-112. doi:10.1111/j.1468-2370.2006.00122.x

Barreto, I. (2010). Dynamic Capabilities: A Review of Past Research and an Agenda for the Future. Journal of Management, 36(1), 256-280. doi:10.1177/0149206309350776

Battistella, C., De Toni, A. F., De Zan, G., \& Pessot, E. (2017). Cultivating business model agility through focused capabilities: A multiple case study. Journal of Business Research, 73, 65-82. doi:10.1016/j.jbusres.2016.12.007

Brady, M., \& Saranga, H. (2013). Innovative business models in healthcare: A comparison between India and Ireland. Strategic Change, 22(5-6), 339-353. doi:10.1002/jsc.1944

Cepeda, G., \& Vera, D. (2007). Dynamic capabilities and operational capabilities: A knowledge management perspective. Journal of Business Research, 60(5), 426-437. doi:10.1016/j.jbusres.2007.01.013

Chesbrough, H. (2010). Business Model Innovation: Opportunities and Barriers. Long Range Planning, 43(2-3), 354-363. doi:10.1016/j.lrp.2009.07.010

Cozzolino, A., Verona, G., \& Rothaermel, F. T. (2018). Unpacking the Disruption Process: New Technology, Business Models, and Incumbent Adaptation. Journal of Management Studies, 55(7), 1166-1202. doi:10.1111/joms.12352

DaSilva, C. M., \& Trkman, P. (2014). Business Model: What It Is and What It Is Not. Long Range Planning, 47(6), 379-389. doi:10.1016/j.lrp.2013.08.004

Demil, B., \& Lecocq, X. (2010). Business Model Evolution: In Search of Dynamic Consistency. Long Range Planning, 43(2-3), 227-246. doi:10.1016/j.lrp.2010.02.004

Di Stefano, G., Peteraf, M., \& Verona, G. (2010). Dynamic capabilities deconstructed: A bibliographic investigation into the origins, development, and future directions of the research domain. Industrial and Corporate Change, 19(4), 1187-1204. doi:10.1093/icc/dtq027

Døving, E., \& Gooderham, P. N. (2008). Dynamic capabilities as antecedents of the scope of related diversification: The case of small firm accountancy practices. Strategic Management Journal, 29(8), 841-857. doi:10.1002/smj.683

Edmondson, A. C., \& McManus, S. E. (2007). Methodological fit in management field research. Academy of Management Review, 32(4), 1246-1264. doi:10.5465/amr.2007.26586086

Eisenhardt, K. M. (1989). Making fast strategic decisions in high-velocity environments. Academy of Management Journal, 32(3), 543-576.

Foss, N. J., \& Saebi, T. (2018). Business models and business model innovation: Between wicked and paradigmatic problems. Long Range Planning, 51(1), 9-21. doi:10.1016/j.lrp.2017.07.006

Gamble, J. R., Brennan, M., \& McAdam, R. (2017). A rewarding experience? Exploring how crowdfunding is affecting music industry business models. Journal of Business Research, 70, 25-36. doi:10.1016/j.jbusres.2016.07.009

Garnaut, R., Song, L., \& Fang, C. (2018). China's 40 years of reform and development: 1978-2018. ANU Press. doi:10.22459/CYRD.07.2018

Hacklin, F., Björkdahl, J., \& Wallin, M. W. (2018). Strategies for business model innovation: How firms reel in migrating value. Long Range Planning, 51(1), 82-110. doi:10.1016/j.lrp.2017.06.009

Jiang, S., Gong, L., Wang, H., \& Kimble, C. (2016). Institution, strategy, and performance: A co-evolution model in transitional China. Journal of Business Research, 69(9), 3352-3360. doi:10.1016/j.jbusres.2016.02.009

Kranz, J. J., Hanelt, A., \& Kolbe, L. M. (2016). Understanding the influence of absorptive capacity and ambidexterity on the process of business model change-the case of on-premise and cloud-computing software. Information Systems Journal, 26(5), 477-517. doi:10.1111/isj.12102 
Landau, C., Karna, A., \& Sailer, M. (2016). Business model adaptation for emerging markets: A case study of a German automobile manufacturer in India. $R \&$ D Management, 46(3), 480-503. doi:10.1111/radm.12201

Li, D.-y., \& Liu, J. (2014). Dynamic capabilities, environmental dynamism, and competitive advantage: Evidence from China. Journal of Business Research, 67(1), 2793-2799. doi:10.1016/j.jbusres.2012.08.007

Li, L., Su, F., Zhang, W., \& Mao, J. Y. (2018). Digital transformation by SME entrepreneurs: A capability perspective. Information Systems Journal, 28(6), 1129-1157. doi:10.1111/isj.12153

Li, S., Easterby-Smith, M., \& Hong, J. F. L. (2019). Towards an understanding of the nature of dynamic capabilities in high-velocity markets of China. Journal of Business Research, 97, 212-226. doi:10.1016/j.jbusres.2018.08.007

Liu, Y., Ndubisi, N. O., Liu, Y., \& Barrane, F. Z. (2020). New product development and sustainable performance of Chinese SMMEs: The role of dynamic capability and intra-national environmental forces. International Journal of Production Economics, 230, 107817. doi:10.1016/j.ijpe.2020.107817

Loon, M., \& Chik, R. (2019). Efficiency-centered, innovation-enabling business models of high tech SMEs: Evidence from Hong Kong. Asia Pacific Journal of Management, 36(1), 87-111. doi:10.1007/s10490-017-9558-4

Massa, L., Tucci, C.L., \& Afuah, A. (2017). A critical assessment of business model research. The Academy of Management Annals, 11(1), 73-104. doi:10.5465/annals.2014.0072

Maxwell, J. A. (2012). A realist approach for qualitative research. Sage (Atlanta, Ga.).

Miller, K., McAdam, R., \& McAdam, M. (2018). A systematic literature review of university technology transfer from a quadruple helix perspective: Toward a research agenda. $R \& D$ Management, 48(1), 7-24. doi:10.1111/radm.12228

NBSC. (2011). China Statistical Yearbook. China Statistics Press.

Paul, J., Parthasarathy, S., \& Gupta, P. (2017). Exporting challenges of SMEs: A review and future research agenda. Journal of World Business, 52(3), 327-342. doi:10.1016/j.jwb.2017.01.003

Peters, M. D., Gudergan, S., \& Booth, P. (2019). Interactive profit-planning systems and market turbulence: A dynamic capabilities perspective. Long Range Planning, 52(3), 386-405. doi:10.1016/j.lrp.2018.03.004

Piekkari, R., Welch, C., \& Paavilainen, E. (2009). The case study as disciplinary convention: Evidence from international business journals. Organizational Research Methods, 12(3), 567-589. doi:10.1177/1094428108319905

Plakoyiannaki,E., Wei, T., \& Prashantham, S. (2019). Rethinking qualitative scholarship in emerging markets: Researching, theorizing, and reporting. Management and Organization Review, 15(2), 217-234. doi:10.1017/mor.2019.27

Saebi, T., Lien, L., \& Foss, N. J. (2017). What Drives Business Model Adaptation? The Impact of Opportunities, Threats and Strategic Orientation. Long Range Planning, 50(5), 567-581. doi:10.1016/j.lrp.2016.06.006

Sapienza, H. J., Autio, E., George, G., \& Zahra, S. A. (2006). A capabilities perspective on the effects of early internationalization on firm survival and growth. Academy of Management Review, 31(4), 914-933. doi:10.5465/ amr.2006.22527465

Sarta, A., Durand, R., \& Vergne, J.-P. (2020). Organizational Adaptation. Journal of Management. Advance online publication. doi:10.1177/0149206320929088 PMID:33424060

Schaffer, B. S., \& Riordan, C. M. (2003). A review of cross-cultural methodologies for organizational research: A bestpractices approach. Organizational Research Methods, 6(2), 169-215. doi:10.1177/1094428103251542

Spieth, P., Schneckenberg, D., \& Matzler, K. (2016). Exploring the linkage between business model (\&) innovation and the strategy of the firm. $R \& D$ Management, 46(3), 403-413. doi:10.1111/radm.12218

Spieth, P., Schneckenberg, D., \& Ricart, J. E. (2014). Business model innovation-state of the art and future challenges for the field. $R \&$ D Management, 44(3), 237-247. doi:10.1111/radm.12071

Spieth, P., Schneider, S., Clauß, T., \& Eichenberg, D. (2019). Value drivers of social businesses: A business model perspective. Long Range Planning, 52(3), 427-444. doi:10.1016/j.lrp.2018.04.004

Suri, H. (2011). Purposeful sampling in qualitative research synthesis. Qualitative Research Journal, 11(2), 63-75. doi:10.3316/QRJ1102063 
Teece, D. J. (2007). Explicating dynamic capabilities: The nature and microfoundations of (sustainable) enterprise performance. Strategic Management Journal, 28(13), 1319-1350. doi:10.1002/smj.640

Teece, D. J. (2010). Business Models, Business Strategy and Innovation. Long Range Planning, 43(2-3), $172-194$. doi:10.1016/j.lrp.2009.07.003

Teece, D. J. (2012). Dynamic capabilities: Routines versus entrepreneurial action. Journal of Management Studies, 49(8), 1395-1401. doi:10.1111/j.1467-6486.2012.01080.x

Teece, D. J. (2014). The Foundations of Enterprise Performance: Dynamic and Ordinary Capabilities in an (Economic) Theory of Firms. The Academy of Management Perspectives, 28(4), 328-352. doi:10.5465/amp.2013.0116

Teece, D. J. (2018). Business models and dynamic capabilities. Long Range Planning, 51(1), 40-49. doi:10.1016/j. lrp.2017.06.007

Teece, D. J., Pisano, G., \& Shuen, A. (1997). Dynamic capabilities and strategic management. Strategic Management Journal, 18(7), 509-533. doi:10.1002/(SICI)1097-0266(199708)18:7<509::AID-SMJ882>3.0.CO;2-Z

To, C. K. M., Au, J. S. C., \& Kan, C. W. (2019). Uncovering business model innovation contexts: A comparative analysis by fsQCA methods. Journal of Business Research, 101, 783-796. doi:10.1016/j.jbusres.2018.12.042

Tsang, E. W. (2013). Case study methodology: Causal explanation, contextualization, and theorizing. Journal of International Management, 19(2), 195-202. doi:10.1016/j.intman.2012.08.004

Vargo, J., \& Seville, E. (2011). Crisis strategic planning for SMEs: Finding the silver lining. International Journal of Production Research, 49(18), 5619-5635. doi:10.1080/00207543.2011.563902

Wang, C. L., \& Ahmed, P. K. (2007). Dynamic capabilities: A review and research agenda. International Journal of Management Reviews, 9(1), 31-51. doi:10.1111/j.1468-2370.2007.00201.x

Weerawardena, J., Mort, G. S., \& Liesch, P. W. (2019). Capabilities development and deployment activities in born global B-to-B firms for early entry into international markets. Industrial Marketing Management, 78, 122-136. doi:10.1016/j. indmarman.2017.06.004

Welch, C., Piekkari, R., Plakoyiannaki, E., \& Paavilainen-Mäntymäki, E. (2011). Theorising from case studies: Towards a pluralist future for international business research. Journal of International Business Studies, 42(5), 740-762. doi:10.1057/ jibs. 2010.55

Winterhalter, S., Zeschky, M. B., Neumann, L., \& Gassmann, O. (2017). Business models for frugal innovation in emerging markets: The case of the medical device and laboratory equipment industry. Technovation, 66, 3-13. doi:10.1016/j. technovation.2017.07.002

Wirtz, B. W., Mathieu, A., \& Schilke, O. (2007). Strategy in high-velocity environments. Long Range Planning, 40(3), 295-313. doi:10.1016/j.lrp.2007.06.002

Yin, R. K. (2003). Case study design. Sage Publications.

Yin, R. K. (2009). Case study research: Design and methods 4th edition. Paper presented at the United States: Library of Congress Cataloguing-in-Publication Data.

Zhao, Y., Von Delft, S., Morgan-Thomas, A., \& Buck, T. (2019). The evolution of platform business models: Exploring competitive battles in the world of platforms. Long Range Planning, 101892.

Zott, C., \& Amit, R. (2007). Business model design and the performance of entrepreneurial firms. Organization Science, 18(2), 181-199. doi:10.1287/orsc.1060.0232

Zott, C., \& Amit, R. (2010). Business Model Design: An Activity System Perspective. Long Range Planning, 43(2-3), 216-226. doi:10.1016/j.lrp.2009.07.004

Zott, C., Amit, R., \& Massa, L. (2011). The Business Model: Recent Developments and Future Research. Journal of Management, 37(4), 1019-1042. doi:10.1177/0149206311406265 
Yulong Liu is a senior lecturer in the Massey Business School, Massey University, New Zealand. His research interests pertain to organizational learning and innovation, emerging technology adoption and disruptive management, global business strategies, and cross-cultural relationship management. He has published articles in such journals as International Business Review, Journal of Business Research, Long Range Planning, International Studies of Management and Organization and Thunderbird International Business Review.

Yang $\mathrm{Yu}$ is a Senior Lecturer from the School of Marketing and International Business, Victoria University of Wellington, New Zealand. His research interests pertain to MNC strategy and structure, emerging markets, organizational status, and more recently family businesses. He has published articles in such journals as Journal of Small Business Management, Journal of Business Research, Long Range Planning, Thunderbird International Business Review, Critical Perspective on International Business, Journal of Business \& Industrial Marketing, and Management Decision. 